\title{
No Association between the Serotonin Transporter-Linked Promoter Region Polymorphism and Either Schizophrenia or Density of the Serotonin Transporter in Human Hippocampus
}

\author{
Lee Naylor, ${ }^{1,2}$ Brian Dean, ${ }^{1}$ Avril Pereira, ${ }^{1}$ \\ Andrew Mackinnon, ${ }^{1,3}$ Alexander Kouzmenko, ${ }^{1}$ and \\ David Copolov ${ }^{1}$ \\ ${ }^{1}$ The Rebecca L. Cooper Research Laboratories, Molecular \\ Schizophrenia Division, Mental Health Research Institute of Victoria, \\ Parkville, Victoria, Australia \\ ${ }^{2}$ Department of Pharmacology, University of Melbourne, Parkville, \\ Victoria, Australia \\ ${ }^{3}$ Department of Psychological Medicine, Monash University, Clayton, \\ Victoria, Australia
}

Accepted September 1, 1998.

\begin{abstract}
Background: Allelic association case-control analysis of a deletion/insertion polymorphism in the serotonin transporter-linked polymorphic region (5-HTTLPR) has suggested associations with unipolar disorder, bipolar disorder, depression, and Alzheimer's disease. Moreover, the heterozygous long form of the 5-HTTLPR has been associated with increased levels of mRNA for the serotonin transporter (5-HTT) and increased serotonin uptake in lymphoblastic cell lines. This study attempts to determine whether there is an association between 5-HTTLPR genotype and schizophrenia or the binding of $\left[{ }^{3} \mathrm{H}\right]$ paroxetine to the human hippocampal 5-HTT.
\end{abstract}

Materials and Methods: DNA from the cerebellum

from 58 schizophrenic and 62 control subjects was used to genotype the 5-HTTLPR. In addition, the relationship between 5-HTTLPR genotype and the affinity and density of $\left[{ }^{3} \mathrm{H}\right]$ paroxetine binding to the hippocampal 5-HTT was assessed.

Results: There were no associations between 5-HTTLPR allotype or genotype and/or the parameters of $\left[{ }^{3} \mathrm{H}\right]$ paroxetine binding to the hippocampal 5-HTT.

Conclusions: Our data suggest that 5-HTTLPR genotype neither confers an increased susceptibility for schizophrenia nor dictates the expression of the 5-HTT in the human hippocampus.

\section{Introduction}

Data from our studies on $\left[{ }^{3} \mathrm{H}\right]$ paroxetine binding in brain tissue obtained at autopsy from schizo-

Address correspondence and reprint requests to: Dr. Brian Dean, Molecular Schizophrenia Division, Mental Health Research Institute of Victoria, Locked Bag 11, Parkville, Victoria 3052, Australia. Phone: (03) 9388 1633; Fax: (03) 9387 5061; E-mail: bdean@cooper.mhri.edu.au phrenic subjects have lead us to suggest that there is a conformational change in the serotonin transporter (5-HTT) in the hippocampus of subjects with this illness $(1,2)$. Moreover, twin and adoption studies strongly suggest that genetic factors are of major etiologic importance in schizophrenia (3). These two factors would suggest that the study of the 5-HTT gene could be 
particularly important in identifying possible genetic factors involved in the etiology of schizophrenia.

The 5-HTT is encoded by a single gene on chromosome 17q11.1-q12, which is organized in 14 exons spanning $\sim 35 \mathrm{~kb}(4)$. Recently, a deletion/insertion polymorphism in the 5 -HTTlinked polymorphic region (5-HTTLPR), $\sim 1 \mathrm{~kb}$ upstream of the transcription initiation site in a $\mathrm{GC}$-rich region, has been identified (5). Moreover, studies of the 5-HTTLPR have suggested an association between 5-HTTLPR genotype and unipolar disorder and bipolar disorder (6) as well as depression (7), anxiety disorders (8) and Alzheimer's disease (9). However, these associations have been challenged in bipolar disorder $(10,11)$ and reported not to be present in schizophrenia $(10,12)$.

The effect of genotype for the 5-HTTLPR and 5-HTT expression has been examined in cell culture expression systems. These studies have shown that the presence of the LL genotype is associated with higher levels of 5-HTT mRNA and an increased rate of serotonin uptake (5). This suggests that the genotype for the 5-HTTLPR could be a factor in controlling levels of 5-HTT in the central nervous system.

The 5-HTT plays a critical role in modulating the termination of serotonergic neurotransmission by the presynaptic neuron (13) and hence is critical in maintaining the stability of serotonergic neurotransmission. Moreover, abnormalities in serotonergic neurotransmission have been implicated in the pathogenesis of diverse psychiatric disorders including schizophrenia $(1,2)$, affective disorders (14), and major depression (15). Given our data showing changes in 5-HTT in brain tissue from subjects with schizophrenia, we have attempted to confirm the presence or absence of an association between the genotype of the 5-HTTLPR and schizophrenia by studying DNA isolated from human cerebellum. Importantly, we have attempted to determine if there is an association between the genotype for the 5-HTTLPR and levels of 5-HTT in the human brain, as is suggested by studies using cell culture techniques (5).

\section{Materials and Methods}

\section{Materials}

All oligonucleotide primers, polymerase chain reaction (PCR) buffer, $\mathrm{MgCl}_{2}$, and deoxyribonucleotides were purchased from Life Technologies;
Taq DNA polymerase was purchased from Biotech International.

COLLECTION OF TISSUE AT AUTOPSY. With Ethics Committee approval, cerebellum tissue was obtained at autopsy from the left brain hemisphere of 58 subjects who had a provisional diagnosis of schizophrenia. Tissue was also obtained from the same brain region from 62 subjects with no history of schizophrenia (controls). The tissue was rapidly frozen and stored at $-70^{\circ} \mathrm{C}$ until required.

In all cases, the diagnosis of schizophrenia was confirmed by a senior psychiatrist and psychologist according to DSM-III-R criteria (16) after extensive case review (17). The control subjects were matched for sex and closely matched for age to the schizophrenic subjects. The majority of deaths of subjects from whom tissue was taken had been witnessed, and in these cases the postmortem interval (PMI) was the interval between death and autopsy. Where death was not witnessed, tissue was only collected if an individual had been seen alive within $5 \mathrm{hr}$ of being found dead. In these cases, the PMI was the interval half-way between the individual being last seen alive and being found dead, to autopsy. All cadavers were refrigerated within $5 \mathrm{hr}$ of being found dead.

\section{DNA Isolation and PCR Amplification}

DNA was extracted from the cerebellum according to standard procedures and stored at $-20^{\circ} \mathrm{C}$ until required. DNA fragments of 524 (L) or 484 bp (S) were generated from the 5-HTTLPR using oligonucleotide primers corresponding to the following nucleotide positions:

$-1,416$ to $-1,397$ (strp5: 5'-GGCGTTGCCGCTCTGAATTGC)

-910 to -889 (strp3: 5'-GAGGGACTGAGCTGGACAACCCAC)

by PCR as described previously (5). Alleles for the 5-HTTLPR were determined by the size of the PCR products after they were resolved by electrophoresis on $2 \%$ agarose gel.

\section{$l^{3}$ H]paroxetine Binding to Particulate Membrane}

The $\left[{ }^{3} \mathrm{H}\right]$ paroxetine binding parameters used in this study were essentially as described in our earlier studies $(1,2)$. However, in this study, these data were combined and additional subjects added so that $\left[{ }^{3} \mathrm{H}\right]$ paroxetine binding data 
Table 1. Allotypic and genotypic frequency distributions for 5-HTTLPR in DNA from schizophrenic and control subjects

\begin{tabular}{|c|c|c|c|c|c|}
\hline & & \multicolumn{2}{|c|}{$\begin{array}{l}\text { Schizo- } \\
\text { phrenic }\end{array}$} & \multicolumn{2}{|c|}{$\begin{array}{l}\text { Nonschizo- } \\
\text { phrenic }\end{array}$} \\
\hline & & $n$ & $\%$ & $n$ & $\%$ \\
\hline \multirow[t]{2}{*}{ Allotype } & $\mathrm{L}$ & 52 & 45 & 67 & 54 \\
\hline & $\mathrm{S}$ & 64 & 55 & 57 & 46 \\
\hline \multirow[t]{3}{*}{ Genotype } & $\mathrm{L} / \mathrm{L}$ & 11 & 19 & 19 & 31 \\
\hline & $\mathrm{L} / \mathrm{S}$ & 30 & 52 & 29 & 47 \\
\hline & $S / S$ & 17 & 29 & 14 & 22 \\
\hline
\end{tabular}

were available on 38 schizophrenic subjects and 41 control subjects.

\section{Statistical Analysis}

The experimental allelic frequencies obtained in this study were compared with predicted frequencies as expected from Hardy-Weinberg equilibrium using a $\chi^{2}$ goodness-of-fit test. Following Sasieni (18), the association between clinical status and the 5-HTTLPR was assessed by a $\chi^{2}$ test on genotypes rather than on the widely used but potentially misleading test based on allelic frequency (18). Statistically significant differences in $\left[{ }^{3} \mathrm{H}\right]$ paroxetine binding between schizophrenic and control subjects divided according to 5-HTTLPR genotypes were assessed using a one-way ANOVA.

\section{Results}

The 5-HTTLPR alleles were in equilibrium in both the schizophrenic and control groups $\left(\chi^{2}=\right.$
$0.121, d f=1, p=0.728$ and $\chi^{2}=0.211, d f=1$, $p=0.646$, respectively; see Table 1 ). In addition, there was no difference in the proportion of individuals carrying any of the 5-HTTLPR genotypes between schizophrenic and control subjects $\left(\chi^{2}=2.31,2 d f, p=0.315\right.$; see Table 1$)$.

There were no differences in the density of 5 -HTT as measured by $\left[{ }^{3} \mathrm{H}\right]$ paroxetine binding in schizophrenic $(\mathrm{F}=0.3127 ; d f=2,35 ; p=0.72)$ or control subjects $(\mathrm{F}=0.55 ; d f=2,38 ; p=$ $0.58)$ categorized by 5-HTTLPR genotype (Table 2). Differences in the $\mathrm{Kd}$ for paroxetine binding between the schizophrenic subjects categorized by genotype approached statistical significance $(\mathrm{F}=3.195 ; d f=2,35 ; p=0.053)$ which was not the case for the control $(\mathrm{F}=0.24$; $d f=2,38 ; p=0.78$ ) subjects divided according to genotype.

\section{Discussion}

This study does not provide data to support the hypothesis that there is an association between the 5-HTTLPR polymorphism and schizophrenia. Thus, this study supports previous studies using DNA isolated from peripheral tissue that suggested that the 5-HTTLPR polymorphism is not a major factor in conferring a genetic susceptibility for schizophrenia $(10,12)$.

Studies of the 5-HTT in lymphoblast cell lines indicated that the presence of the LL 5-HTTLPR was associated with increased levels of 5-HTT mRNA and increased uptake of serotonin by the 5-HTT (5). By contrast, our study failed to show an association between 5-HTTLPR genotype and the density of $\left[{ }^{3} \mathrm{H}\right]$ paroxetine binding in the hippocampus of schizophrenic or control subjects. As the density of $\left[{ }^{3} \mathrm{H}\right]$ paroxetine binding is a good measure of the density of 5-HTT, our data

Table 2. The parameters for $\left[{ }^{3} \mathrm{H}\right]$ paroxetine binding to the hippocampal 5 -HTT in schizophrenic and control subjects separated according to 5-HTTLPR genotype

\begin{tabular}{|c|c|c|c|c|c|c|}
\hline & \multicolumn{3}{|c|}{ Schizophrenic } & \multicolumn{3}{|c|}{ Nonschizophrenic } \\
\hline & $n$ & $\mathrm{Kd}^{\mathrm{a}}$ & $B_{\max }{ }^{\mathbf{b}}$ & $n$ & $\mathrm{Kd}^{\mathrm{a}}$ & $B_{\max }{ }^{\mathbf{b}}$ \\
\hline $\mathrm{L} / \mathrm{L}$ & 11 & $0.59 \pm 0.07$ & $164 \pm 20$ & 13 & $0.25 \pm 0.03$ & $127 \pm 19$ \\
\hline $\mathrm{L} / \mathrm{S}$ & 16 & $0.42 \pm 0.05$ & $153 \pm 11$ & 18 & $0.24 \pm 0.02$ & $144 \pm 10$ \\
\hline$S / S$ & 11 & $0.40 \pm 0.05$ & $146 \pm 17$ & 10 & $0.27 \pm 0.03$ & $150 \pm 17$ \\
\hline
\end{tabular}

${ }^{\mathrm{a}} \mathrm{nM}$.

${ }^{\mathrm{b}} \mathrm{fmol} / \mathrm{mg}$ protein. 
do not support the presence of a simple relationship between the genotype for 5-HTTLPR and levels of 5-HTT seen in the lymphoblast cell lines. Moreover, there was no association between the 5-HTTLPR genotype and the increased affinity of hippocampal $\left[{ }^{3} \mathrm{H}\right]$ paroxetine binding as we have reported previously $(1,2)$; again, this suggests that the 5-HTTLPR does not contribute significantly to this change in 5-HTT.

In summary, this study has failed to show any associations between 5-HTTLPR genotype and schizophrenia, the level of 5-HTT in the human hippocampus, or the change in affinity of $\left[{ }^{3} \mathrm{H}\right]$ paroxetine binding to the 5-HTT in the hippocampus from schizophrenic subjects. In addition, these data show that studies on the effects of polymorphisms on end protein expression observed in cell culture systems may not be readily applicable to the intact central nervous system.

\section{Acknowledgments}

This work was funded in part by funding from the Bethlehem Griffiths Research Foundation, the State Government of Victoria, and the Wood's Family Trust. The authors wish to acknowledge the assistance of Professor Nicholas Keks and Christine Hill in confirming the provisional diagnoses of schizophrenia. In addition, the authors would like to thank Mr. Geoffrey Pavey and Dr. Kenneth Opeskin as well as the staff of the Victorian Institute of Forensic Medicine for assistance in collection of brain tissue.

\section{References}

1. Dean B, Opeskin K, Pavey G, et al. (1995) $\left[{ }^{3} \mathrm{H}\right]$ Paroxetine binding is altered in the hippocampus but not the frontal cortex or caudate nucleus from subjects with schizophrenia. J. Neurochem. 64: 1197-1202.

2. Naylor L, Dean B, Opeskin K, et al. (1996) Changes in the serotonin transporter in the hippocampus of subjects with schizophrenia identified using $\left[{ }^{3} \mathrm{H}\right]$ paroxetine. J. Neural Transm. 103: 749-757.

3. Kendler KS, Diehl SR. (1993) The genetics of schizophrenia: a current, genetic-epidemiologic perspective. Schizophr. Bull. 19: 261-285.

4. Lesch KP, Balling U, Gross J, Strauss K, Murphy DL, Riederer P. (1994) Organisation of the human serotonin transporter gene. J. Neural Transm. 95: 157-162.

5. Heils A, Teufel A, Petri S, Stober G, Bengel D, Lesch KP. (1996) Allelic variation of human serotonin transporter gene expression. J. Neurochem. 6: 561-567.

6. Furlong R, Ho L, Walsh C, et al. (1998) Analysis and meta-analysis of two serotonin transporter gene polymorphisms in bipolar and unipolar affective disorders. Am. J. Med. Genet. 81: 58-63.

7. Collier DA, Stober G, Li T, et al. (1996) A novel functional polymorphism within the promoter of the serotonin transporter gene: possible role in susceptibility to affective disorders. Mol. Psychiatry 1: 453-460.

8. Lesch KP, Bengal D, Heils A, et al. (1996) Association of anxiety-related traits with a polymorphism in the serotonin transporter gene regulatory region. Science 274: 1527-1531.

9. Li T, Holmes C, Sham P, et al. (1997) Allelic functional variation of serotonin transporter expression is a susceptibility factor for late onset Alzheimer's disease. Neuroreport 8: 683-686.

10. Mendes-de-Oliveira J, Otto $\mathrm{P}$, Vallada $\mathrm{H}$, et al. (1998) Analysis of a novel functional polymorphism within the promoter region of the serotonin transporter gene (5-HTT) in Brazilian patients affected by bipolar disorder and schizophrenia. Am. J. Med. Genet. 81: 225-227.

11. Hoehe M, Wendel B, Grunewald I, et al. (1998) Serotonin transporter (5-HTT) gene polymorphism are not associated with susceptibility to mood disorders. Am. J. Med. Genet. 81: 1-3.

12. Stober G, Jatzke S, Heils A, et al. (1998) Susceptibility for schizophrenia is not influenced by a functional insertion/deletion variant in the promoter of the serotonin transporter gene. Eur. Arch. Psychiatr. Clin. Neurosci. 248: 82-86.

13. Sanders-Bush E. (1988) The Serotonin Receptors. Humana Press, Clifton, NJ.

14. Stahl S, Woo D, Mefford I, Berger P, Ciaranello R. (1983) Hyperserotonemia and platelet serotonin uptake in schizophrenia and affective disorders. Am. J. Psychiatry 140: 26-31.

15. Meltzer HY. (1989) Serotonergic dysfunction in depression. Br. J. Psychiatry Suppl. 8: 25-31.

16. American Psychiatric Association. (1994) Diagnostic and Statistical Manual of Mental Disorders, Fourth Edition (DSM-IV). Washington, DC: American Psychiatric Press.

17. Hill C, Keks N, Roberts S, Opeskin K, Dean B, Copolov DL. (1996) Postmortem brain studies in schizophrenia: the problems of diagnosis. Am. J. Psychiatry 153: 533-537.

18. Sasieni, PD. (1997) From genotype to genes: doubling the sample size. Biometrics 53: 1253-1261. 